\title{
Transport Geography Workshop 2018 at Masaryk University
}

\author{
Jiří Dujka, Daniel Seidenglanz, Simona Surmařová ${ }^{1}$
}

The Department of Geography of the Faculty of Science of the Masaryk University hosted the fourth annual meeting of transport geographers from the Czech Republic and Slovakia on October 11 and 12, 2018. The Transport Geography Workshop is a regularly occurring event held every two years by a different academic workplace. The workshop takes the form of an informal platform through which participants are acquainted with current events in the field of Czech and Slovak transport geography. The focus of the workshop is actually in line with current discussions about the present and the future of our discipline, which are taking place at other levels as well, see, for example, current texts in the key journal Progress in Human Geography (Cresswell, 2012, 2014; Merriman, 2015, 2016, 2017; Lin, 2018; Schwanen, 2016, 2017, 2018).

This year's Transport Geography Workshop was marked by several innovations. The workshop was first included in the project "New Mobility - High Speed Transport Systems and the Transport-Related Human Behavior " (CZ.02.1.01 / 0.0 / 0.0 / 16_026 / 0008430) and was also held under the auspices of ITREGEP (Institute for Transport Economics, Geography and Politics) from the Faculty of Economics and Administration of Masaryk University. It was held as a two-day workshop for the first time and was accompanied by an expert excursion along the Brno railway junction. A total of 30 people participated in the workshop this year. Participants and lecturers mainly included specialists and students of Czech and Slovak universities (Masaryk University, Charles University in Prague, University of South Bohemia in České Budějovice, Comenius University in Bratislava and Jan Evangelista Purkyně University in Ústí nad Labem), research institutes (Geographical Institute of the Slovak Academy in Bratislava) as well as representatives of carriers (Czech Railways), transport organizers (ROPID) and municipalities (Brno City Council).

The Thursday program consisted of a professional field lecture. Under the name Brno Railway Junction or where exactly will the new one be? a guided tour around Brno's main railway station, Vaňkovka, Zvonařka and parts of the South Center took place under the leadership of Jiří Dujka (Seidenglanz et al., 2016). Participants in the lecture could learn about the past, present and future of the Brno railway junction and personal-

\footnotetext{
${ }^{1}$ Department of Geography, Faculty of Science, Masaryk University, Kotlářská 2, 611 37, Brno jiri.dujka@mail.muni.cz, seidenglanz@geogr.muni.cz, simona.surmarova@gmail.com
}

(C) 2019 by the authors; licensee Review of Economic Perspectives / Národohospodářský obzor, Masaryk University, Faculty of Economics and Administration, Brno, Czech Republic. This article is an open access article distributed under the terms and conditions of the Creative Commons Attribution 3.0 license, Attribution - Non Commercial - No Derivatives. 
ly visit and see the places that are the subject of discussions about the "transfer of the station". The lecture was completed on the provisional platforms of Dolní nádraží (Dolní Railway Station) in Brno, which may be transformed into the new modern main railway station in the future.

The Friday program of the workshop was ceremonially launched with the organizers wishing prof. Milan Viturka a happy birthday and thanking him for his contribution in the field of transport geography. After this pleasant opening, the main part of the workshop followed, which included a total of seven presentations. The first lecture on MultiCriteria Assessment of Transport Projects was presented by Milan Viturka himself (Viturka, 2014). He primarily dealt with methods and indicators that can be used to evaluate transport projects, both road and rail. It is still a current topic and will be further addressed in the context of proposed high-speed railways within the project "New Mobility", on which prof. Viturka also participates.

After the short coffee break, there were two papers, whose common denominator was describing developments in the selected area of transport geography. Stanislav Kraft (Kraft, Halás, Vančura, 2014) in his paper Too many questions - Too few answers: Where has Czechoslovak transport geography shifted to? set the difficult task of identifying and commenting on key personalities and processes that influence the development of transport geography. During the lecture he admitted that the topic is extremely extensive, as the current transport geography in the Czechoslovak area naturally responds to a series of currents, questions and challenges, both of an international nature as well as specific local factors. The collective paper of Miroslav Marada and Tomás Květoň (Chmelík, Marada, 2014; Marada, Květoň, 2016), named Changes in the Mobility of the Czech Population after 2000, deals in detail with the analysis of the current possibilities of research on mobility and the transport phenomena, while the authors also considered the potential of so-called big data, i.e. residual signaling data of mobile operators. Besides the theoretical considerations about the benefits and shortcomings of this data, the authors also presented several analyses of the mobility of persons based on work with the mentioned big data, namely the study of the urban environment of České Budějovice as well as research in the wider areas of Humpolec and Dačice.

The first afternoon block was reserved for two complementary contributions concerning Bratislava and the territory of its urban region. Daniel Michniak (Michniak et al., 2015) talked about Selected transport problems in Bratislava and its hinterland. Among them, according to the author, there is a lack of transport infrastructure, i.e. missing parts of core roads, a completely absent ring road around the city, the insufficient or poorquality rail infrastructure as well as limits in the construction and maintenance of the tram network. Daniel Michniak also spoke about organizational difficulties in public transport, both in urban and rail passenger transport. The paper Horizon 2022: the year of completion of major highway projects around Bratislava Pavol Durček and Marcel Horňák (Durček, Horňák, 2016; Horňák, Struhár, Pšenka, 2015) followed up on the previous paper and more closely dealt with the problem of the highway connection of Bratislava. The authors mentioned in particular a study of changes in transport accessibility after completing part of the D4 ring road in the southeastern quadrant of the urban region and the linked R7 expressway serving the suburban strip towards Šamorín and Dunajská Streda. Within the framework of this topic, the issue of the model of transport service on the concurrent railway line Bratislava - Komárno was discussed. 
The last lecture block deals with the themes of the current approaches to mobility, especially with regard to its possible future development. The paper Strategic tools to support municipal decision-making in sustainable mobility by Hana Brůhová Foltýnová (Rojas-Rueda et al., 2016) offered an insight into an important but often overlooked aspect of mobility, namely the practical application of the principles of sustainable mobility to city space through local policies. In this context, Hana Brůhová Foltýnová also introduced a research method enabling the in-depth analysis of semi-structured interviews. The program of the workshop was concluded by the main organizer of the meeting, Daniel Seidenglanz (Seidenglanz et al., 2016; Mulíček, Osman, Seidenglanz, 2016), with his paper entitled Automobility: Quo vadis? In addition to a short retrospective view of the development of automobility in socialist and post-socialist Czechoslovakia, he focused on issues that may affect automobility in the near future. These include, in particular, autonomous vehicles, at least partial de-privatization of mobility and a much wider use of smart-car technologies and telematics in the management of passenger cars. The debate on automobility, particularly in relation to cities, is an extremely topical subject in the Czech Republic, as is indeed shown by the excited debate about residential parking in Prague and Brno.

This year's fourth edition of the Transport Geography Workshop has again fulfilled its basic objective, namely the meeting of experts in the field of transport geography, the presentation of current research topics and a rich and interesting discussion. As many of the participants complained, such meetings usually bring more questions than answers. However, such a conclusion can also be seen in a positive light, as this means that transport geography still has its place and target in the set of geographic fields. Indeed, if a scientific discipline does not come up with new questions, it is probably stagnating or declining.

Open and thus unanswered questions lead the way for the next meeting of Czech and Slovak experts at the next edition of the Transport Geography Workshop. This should take place in the late summer or autumn of 2020, again under the heading "New mobility - high-speed transport systems and transport-related human behavior ".

\section{Funding}

This report is the output of the project called "New Mobility - High-Speed Transport Systems and Transport-Related Human Behaviour", Reg. No. CZ.02.1.01/0.0/0.0/16_026/0008430, co-financed by the "Operational Programme Research, Development and Education".

\section{References}

CHMELÍK, J. \& MARADA, M. (2014). Assessment of the Impact of a New Motorway Connection on the Spatial Distribution and Intensity of Traffic Flows: A Case Study of the D47 Motorway, Czech Republic. Moravian Geographical Reports, Brno: Geonics Institute. Vol. 22, issue 4, p. 14-24, DOI: 10.1515/mgr-2014-0020. 
CRESSWELL, T. (2012). Mobilities II: still. Progress in human geography, 36 (5), 645 653.

CRESSWELL, T. (2014). Mobilities III: moving on. Progress in Human Geography, 38(5), 712-721. DOI: 10.1177/0309132514530316.

ĎURČEK, P. \& HORŇÁK, M. (2016). Population potential within the urban environment and urban railway intra-network opportunities in Bratislava (Slovakia). Moravian Geographical Reports, Brno: Geonics Institute. Vol. 24, issue 4, p. 52-64, DOI: 10.1515/mgr-2016-0022.

HORŇÁK, M., STRUHÁR, P. \& PŠENKA, T. (2015). Evaluation of high-standard public transport centres in the Slovak Republic. Bulletin of Geography-Socio-Economic Series. Warsaw: De Gruyter Open Ltd. Vol. 30, issue 30, p. 59-70, DOI: 10.1515/bog2015-0035.

KRAFT, P., M. \& HALÁS, VANČURA, M. (2014). The Delimitation of Urban Hinterlands Based on Transport Flows: A Case Study of Regional Capitals in the Czech Republic. Moravian Geographical Reports, Brno: Geonics Institute. Vol. 22, issue 1, p. 24 32, DOI: $\underline{10.2478 / \mathrm{mgr}-2014-0003}$.

LIN, W. (2018). Transport provision and the practice of mobilities production. Progress in Human Geography, 42(1), 92-111. DOI: 10.1177/0309132516666189

MARADA, M. \& KVĚTOŇ, V. (2016). Transport Supply and Demand Changes in Relation to Unemployment: Empirical Evidence from the Czech Republic in a Time of Crisis. Tijdschrift voor Economische en Sociale Geografie, Hoboken: Wiley. Vol. 107, issue 5, p. 611-627, DOI: 10.1111/tesg.12186.

MERRIMAN, P. (2015). Mobilities I: departures. Progress in Human Geography, 39(1), 87-95. DOI: $\underline{10.1177 / 0309132514527030}$

MERRIMAN, P. (2016). Mobilities II: Cruising. Progress in Human Geography, 40(4), 555-564. DOI: $\underline{10.1177 / 0309132515585654}$

MERRIMAN, P. (2017). Mobilities III: Arrivals. Progress in Human Geography, 41(3), 375-381. DOI: $10.1177 / 0309132516635948$

MICHNIAK, D., WIĘCKOWSKI, M., STĘPNIAK, M. \& ROSIK, P. (2015). The impact of selected planned motorways and expressways on the potential accessibility of the Polish-Slovak borderland with respect to tourism development. Moravian Geographical Reports, Brno: Geonics Institute. Vol. 23, issue 1, p. 13-20, DOI: 10.1515/mgr-2015-0002.

MULÍČEK, O., OSMAN, R. \& SEIDENGLANZ, D. (2016). Time-space rhythms of the city - The industrial and postindustrial Brno. Environment and Planning A. Thousand

Oaks: Sage Publications. Vol. 48, issue 1, pp. 114-131, DOI: 10.1177/0308518X15594809.

ROJAS-RUEDA, D., DE NAZELLE, A., ANDERSEN, Z. J., BRAUNFAHRLÄNDER, C., BRUHA, J., BRUHOVA FOLTYNOVA, H., DESQUEYROUX, H., PRAZNOCZY, C., RAGETTLI, M. S., TAINIO, M. \& NIEUWENHUIJSEN, M. J. 
(2016). Health Impacts of Active Transportation in Europe. Plos One, San Francisco: Public Library Science. Vol. 11, issue 3, DOI: 10.1371/journal.pone.0149990

SCHWANEN, T. (2016). Geographies of transport and: Reinventing and field?. Progress in Human Geography, 40(1), 126-137. DOI: $\underline{10.1177 / 0309132514565725}$

SCHWANEN, T. (2017). Geographies of transport II: Reconciling the general and the particular. Progress in Human Geography, 41(3), 355-364. DOI: $\underline{10.1177 / 0309132516628259}$

SCHWANEN, T. (2018). Geographies of transport III: New spatialities of knowledge production?. Progress in Human Geography, 42(3), 463-472. DOI: $10.1177 / 0309132517699925$

SEIDENGLANZ, D., KVIZDA, M., NIGRIN, T., TOMEŠ, Z. \& DUJKA, J. (2016). Czechoslovak light rail - Legacy of socialist urbanism or opportunity for the future? Journal of Transport Geography, Oxford: Elsevier, vol. 54, p. 414-429. ISSN 0966-6923. DOI: 10.1016/j.jtrangeo.2016.02.011.

VITURKA, M. (2014). Integrative Model for Evaluation of Development Potentials of Regions and Its Application on an Example of the Czech Republic. E \& M Ekonomie a management. Vol. 17, issue 4, pp. 4-19, DOI: 10.15240/tul/001/2014-4-001. 